\title{
Transmission dynamic of methicillin-resistant Staphylococcus aureus in a medical intensive care unit
}

\author{
S Hugonnet ${ }^{*}$, I Hall${ }^{2}$, I Barrass ${ }^{2}$, S Leach $^{2}$, D Pittet $^{1}$ \\ From International Conference on Prevention \& Infection Control (ICPIC 2011) \\ Geneva, Switzerland. 29 June - 2 July 2011
}

\section{Introduction / objectives}

Intensive care units (ICUs) play an important role in MRSA epidemiology. Although successful interventions are usually multimodal, the relative efficacy of single measures remains unknown. We developed a mathematical model to explore the transmission dynamic of MRSA and assess several control strategies.

\section{Methods}

A discrete time individual-based stochastic model was built and calibrated on the number of crosstransmissions obtained through prospective surveillance. Most of the input parameters were derived from locally-acquired data. After model fitting and sensitivity analysis, several screening and isolation policies were tested by simulating the number of crosstransmissions and isolation-days under various scenarios.

\section{Results}

The three unknown values were fitted to the model. Under the used assumptions, the environment played a negligible role. The number of crosstransmissions increased by almost $40 \%$ if only alert patients are screened and isolated, by about $50 \%$ if isolation is put in place only after the results of the admission screening become available, and over $60 \%$ in the absence of admission screening and isolation. The method used (culture or PCR) for admission screening had no impact on the number of crosstransmissions. Systematic regular screening during ICU stay provided no added-value.

\section{Conclusion}

Aggressive admission screening and isolation are effective to reduce the number of crosstransmission. Colonized HCW may play an important role in MRSA transmission and HCW screening should be reinforced.

\section{Disclosure of interest}

None declared.

\section{Author details}

'University of Geneva Hospitals, Geneva, Switzerland. ${ }^{2}$ Health Protection

Agency, London, UK.

Published: 29 June 2011

doi:10.1186/1753-6561-5-S6-073

Cite this article as: Hugonnet et al:: Transmission dynamic of methicillinresistant Staphylococcus aureus in a medical intensive care unit. BMC Proceedings 2011 5(Suppl 6):O73.

Submit your next manuscript to BioMed Central and take full advantage of:

- Convenient online submission

- Thorough peer review

- No space constraints or color figure charges

- Immediate publication on acceptance

- Inclusion in PubMed, CAS, Scopus and Google Scholar

- Research which is freely available for redistribution

\section{Ciomed Central}

(c) 2011 Hugonnet et al; licensee BioMed Central Ltd. This is an open access article distributed under the terms of the Creative Commons Attribution License (http://creativecommons.org/licenses/by/2.0), which permits unrestricted use, distribution, and reproduction in any medium, provided the original work is properly cited. 